\title{
A New Diterpenoid with Antitumor Cytotoxicity from Millipede
}

\section{Zhimei Shang $\oplus^{1,2}$, Yike Fang $\oplus^{1,2}$, Zongyu Yang $\oplus^{1,2}$, Wanli Luo $\oplus^{1,2}$, Xiaofei Li $\oplus^{* 1}$ and Shiji Xiao ${ }^{*}{ }^{* 1,2}$}

\author{
${ }^{1}$ School of pharmacy, Zunyi Medical University, Zunyi, Guizhou 563000 \\ ${ }^{2}$ Key Laboratory of Basic Pharmacology of Ministry of Education and Joint International \\ Research Laboratory of Ethnomedicine of Ministry of Education, Zunyi Medical University, \\ Zunyi, Guizhou 563000
}

(Received July 16, 2021; Revised August 19, 2021; Accepted August 25, 2021)

\begin{abstract}
A new diterpenoid, namely millipedine A (10), along with nine known compounds (1-9), were isolated from the methanol extract of Millipede. Their structures were established on the basis of spectroscopic analysis including one and two-dimensional NMR spectroscopy and comparison with previously reported data. New compound showed moderate cytotoxicity against A549, HCT-116, and SW1990 cell lines in MTT assay.
\end{abstract}

Keywords: Millipede; diterpenoid; antitumor activities. () 2021 ACG Publications. All rights reserved.

\section{Insect Source}

Millipede is a traditional Chinese medicine, derived from dried worm of the Myriopoda, distributed mainly among Gansu, Guangxi, and Sichuan provinces of China [1]. The experimental sample was purchased from Bozhou City, Anhui province, People's Republic of China, in November 2018, and identified as Millipede by Prof. Xiao-Fei Li, Zunyi Medical University. A voucher specimen (ZMCNo. 20181021) of the worm was deposited at the herbarium of the School of Pharmacy, Zunyi Medical University.

\section{Previous Studies}

The antitumor pharmacological activities of diplopoda family have been reported [2-4]. As far as we know, no systematic chemical component investigations have been reported so far for Millipede.

\footnotetext{
* Corresponding authors: E-mail: lixiaofei35@zmu.edu.cn (Xiaofei Li); xiaoshiji84@163.com (Shiji Xiao).
} 
A new terpenoid from Millipede

\section{Present Study}

Dried and powdered whole parts of Millipede $(5.8 \mathrm{~kg})$ was extracted with $98 \%$ methanol under reflux three times (each $3 \mathrm{~h}$ ) to give an extract $(176.0 \mathrm{~g})$, which was suspended in $\mathrm{H}_{2} \mathrm{O}(2 \mathrm{~L})$ and extracted with cyclohexane $(3 \times 2 \mathrm{~L})$, ethyl acetate $(3 \times 2 \mathrm{~L})$ and $n$-butanol $(3 \times 2 \mathrm{~L})$ successively. After removing the solvent to obtain the cyclohexane extract $(70.0 \mathrm{~g})$, the ethyl acetate extract $(25.02 \mathrm{~g})$ and the $n$-butanol extract $(23.84 \mathrm{~g})$, respectively. The cyclohexane extract and ethyl acetate extract was combined and separated by silica gel medium pressure column chromatography $(\mathrm{CC})(70 \times 460 \mathrm{~mm}$, petroleum ether-ethyl acetate $20: 1 \rightarrow 0: 1$ ) to give eleven fractions (Fr.1-11). Fr.5 was purified by recrystallization to give cholesterol $(11.8 \mathrm{mg})$ [7]. Fr.4 was separated by silica gel medium pressure CC $(26 \times 460 \mathrm{~mm}$, petroleum ether-ethyl acetate $10: 1 \rightarrow 0: 1)$ to give eight sections (Fr.4.1-4.8). Fr.4.3 was separated by silica gel medium pressure CC $(26 \times 460 \mathrm{~mm}$, petroleum ether-ethyl acetate $20: 1 \rightarrow 5: 1)$ to give five subfractions (Fr.4.3.1-4.3.5). Fr.4.3.2 was purified by semi-preparative HPLC eluted with $96 \%$ methanol $(1.0 \mathrm{~mL} / \mathrm{min})$ to obtain cholest-4-en-3-one $\left(7.3 \mathrm{mg}, t_{\mathrm{R}} 23.0 \mathrm{~min}\right)$ [8]. Fr.4.4 was further separated by semi-preparative HPLC eluted with $95 \%$ methanol $(1.2 \mathrm{~mL} / \mathrm{min})$ to obtain ergosta-4,6,8(14),22-tetraen-3-one (6.9 mg, $t_{\mathrm{R}} 12.2 \mathrm{~min}$ ) [9]. Fr.9 was purified by Sephadex LH-20 CC to afford five subfractions (Fr.9.1-9.5). Fr.9.4 was further separated by semi-preparative HPLC eluted with $83 \%$ methanol $(6.0 \mathrm{~mL} / \mathrm{min})$ to afford three subfractions (Fr.9.4.1-9.4.3). Fr.9.4.3 was purified by normal phase HPLC eluted with $83 \% n$-hexane and $17 \%$ isopropanol $(3.0 \mathrm{~mL} / \mathrm{min})$ to obtain

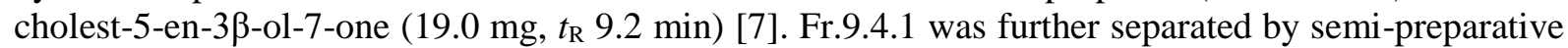
HPLC eluted with $82 \%$ methanol $(6.0 \mathrm{~mL} / \mathrm{min})$ to yield aurantiamide acetate $\left(9.6 \mathrm{mg}, t_{\mathrm{R}} 5.9 \mathrm{~min}\right)$ [10]. Fr.9.5 was separated by Sephadex LH-20 CC to afford seven subfractions (Fr.9.5.1-9.5.7). Fr.9.5.3 was further separated by semi-preparative HPLC eluted with $96 \%$ methanol $(25.0 \mathrm{~mL} / \mathrm{min})$ to obtain six subfractions (Fr.9.5.3.1-9.5.3.6). Fr.9.5.3.6 was purified by semi-preparative HPLC eluted with $91 \%$ methanol $(4.0 \mathrm{~mL} / \mathrm{min})$ to give four subfractions (Fr.9.5.3.6.1-9.5.3.6.4). Fr.9.5.3.6.4 was further separated by semi-preparative HPLC eluted with $90 \%$ methanol $(0.8 \mathrm{~mL} / \mathrm{min})$ to yield 3-[(Z)-octadec9-enoxy]propane-1,2-diol (25.3 mg, $\left.t_{\mathrm{R}} 12.6 \mathrm{~min}\right)$ [11].

The $n$-butanol extract $(23.84 \mathrm{~g})$ was separated by silica column $(100 \times 800 \mathrm{~mm}$, petroleum etherethyl acetate $5: 1 \rightarrow 0: 1)$ to give three fractions (Fr.A-C). Fr.2 was purified by Sephadex LH-20 CC to afford three subfractions (Fr.B.1-B.3). Fr.2.2 was separated by semi-preparative HPLC eluted with $70 \% \rightarrow 80 \% \rightarrow 90 \% \rightarrow 100 \%$ methanol $(20.0 \mathrm{~mL} / \mathrm{min})$ to give eight sections (Fr.B.2.1-B.2.8). Fr.B.2.8 was purified by recrystallization to yield palmitic acid (14.0 mg) [12]. Fr.C was fractionated by semipreparative HPLC eluted with $40 \% \rightarrow 80 \% \rightarrow 100 \%$ methanol $(20.0 \mathrm{~mL} / \mathrm{min})$ to afford six subfractions (Fr.C.1-C.6). 1H-indole-3-carbaldehyde (9.9 mg) [13] was obtained from Fr.C.5 by repeated crystallization. Fr.C.4 was further separated by semi-preparative HPLC eluted with $20 \%$ methanol (4.0 $\mathrm{mL} / \mathrm{min})$ to yield $p$-hydroxybenzaldehyde $\left(3.9 \mathrm{mg}, t_{\mathrm{R}} 11.0 \mathrm{~min}\right)$ [14]. Fr.C.6 was separated by Sephadex LH-20 CC to afford four subfractions (Fr.C.6.1-C.6.4). Fr.C.6.4 was purified by recrystallization to yield compound $\mathbf{1 0}(7.3 \mathrm{mg})$.

Millipedine A (10): white powder; $[\alpha]_{\mathrm{D}}^{20}=+7.49(c=0.08, \mathrm{MeOH}) ; \mathrm{IR} v_{\max }(\mathrm{KBr}):=3400,2925$, $1600 \mathrm{~cm}^{-1} ;{ }^{1} \mathrm{H}$ NMR $\left(600 \mathrm{MHz}, \mathrm{CDCl}_{3}\right): \delta(\mathrm{ppm})=0.94\left(3 \mathrm{H}, \mathrm{s}, 19-\mathrm{CH}_{3}\right), 0.99\left(3 \mathrm{H}, \mathrm{s}, 18-\mathrm{CH}_{3}\right), 1.18$ $\left(3 \mathrm{H}, \mathrm{s}, 20-\mathrm{CH}_{3}\right), 1.27(1 \mathrm{H}, \mathrm{m}, \mathrm{H}-5), 1.28(1 \mathrm{H}, \mathrm{m}, \mathrm{H}-1), 1.28(1 \mathrm{H}, \mathrm{m}, \mathrm{H}-3), 1.32(3 \mathrm{H}, \mathrm{d}, J=7.1 \mathrm{~Hz}, 17-$ $\left.\mathrm{CH}_{3}\right), 1.33\left(3 \mathrm{H}, \mathrm{d}, J=7.1 \mathrm{~Hz}, 16-\mathrm{CH}_{3}\right), 1.64(1 \mathrm{H}, \mathrm{m}, \mathrm{H}-6), 1.83(1 \mathrm{H}, \mathrm{ddd}, J=12.3,4.1,2.2 \mathrm{~Hz}, \mathrm{H}-3)$, $1.91(1 \mathrm{H}, \mathrm{m}, \mathrm{H}-6), 2.55(1 \mathrm{H}, \mathrm{m}, \mathrm{H}-1), 2.75(1 \mathrm{H}, \mathrm{m}, \mathrm{H}-7), 2.95(1 \mathrm{H}, \mathrm{m}, \mathrm{H}-7), 3.26(1 \mathrm{H}, \mathrm{m}, \mathrm{H}-15), 4.01$ $(1 \mathrm{H}, \mathrm{tt}, J=11.5,4.1 \mathrm{~Hz}, \mathrm{H}-2), 6.50(1 \mathrm{H}, \mathrm{d}, J=8.5 \mathrm{~Hz}, \mathrm{H}-11), 6.98(1 \mathrm{H}, \mathrm{d}, J=8.5 \mathrm{~Hz}, \mathrm{H}-12) ;{ }^{13} \mathrm{C}$ NMR $\left(150 \mathrm{MHz}, \mathrm{CDCl}_{3}\right): \delta(\mathrm{ppm})=19.2\left(\mathrm{CH}_{2}, \mathrm{C}-6\right), 20.5\left(\mathrm{CH}_{3}, \mathrm{C}-16\right.$ and $\left.\mathrm{C}-17\right), 22.7\left(\mathrm{CH}_{3}, \mathrm{C}-19\right)$, $26.3\left(\mathrm{CH}_{3}, \mathrm{C}-20\right), 27.5(\mathrm{CH}, \mathrm{C}-15), 28.7\left(\mathrm{CH}_{2}, \mathrm{C}-7\right), 33.5\left(\mathrm{CH}_{3}, \mathrm{C}-18\right), 34.9$ (C, C-4), $39.6(\mathrm{C}, \mathrm{C}-10)$, $48.9\left(\mathrm{CH}_{2}, \mathrm{C}-1\right), 49.1(\mathrm{CH}, \mathrm{C}-5), 51.0\left(\mathrm{CH}_{2}, \mathrm{C}-3\right), 66.1(\mathrm{CH}, \mathrm{C}-2), 114.6(\mathrm{CH}, \mathrm{C}-11), 122.9(\mathrm{CH}, \mathrm{C}-$ 12), 131.4 (C, C-13), 133.7 (C, C-8), 142.3 (C, C-9), 152.4 (C, C-14); HR-APCI-MS: m/z 301.2163 $[\mathrm{M}-\mathrm{H}]^{-}$(calcd. 301.2168 for $\mathrm{C}_{20} \mathrm{H}_{29} \mathrm{O}_{2}^{-}$).

Cell Viability Assay: A549, HCT-116 and SW1990 cell lines was obtained from the Cell Bank of the Zunyi Medical University. The cells were maintained in DMEM containing $10 \%$ fetal bovine serum 
(Taixin Bio Technol Co., Beijing, China) at $37{ }^{\circ} \mathrm{C}$ in a humidified incubator containing $5 \% \mathrm{CO}_{2}$. The MTT assay was used to evaluate A549, HCT-116 and SW1990 cells viability. Briefly, A549, HCT116 and SW1990 cells were plated in 96-well plates (500 cells/well) for $12 \mathrm{~h}$ and then incubated with compound 10 in various concentrations for an additional $48 \mathrm{~h}$. Then, the prepared MTT solution (20 $\mu \mathrm{L}, 5 \mathrm{mg} / \mathrm{mL}$ ) was added, and the cells were incubated for another $2 \mathrm{~h}$. After the formazan that formed was fully dissolved in DMSO and the absorbance was read at $490 \mathrm{~nm}$ on a microplate reader. Data were analyzed using GraphPad Prism 6 software, and nonlinear regression analysis (dose-response) was used to determine the $\mathrm{IC}_{50}$.

The diterpenoid compound millipedine A (10) (Figure 1) was obtained from the methanol extract of Millipede by semi-preparative HPLC purification and recrystallization.

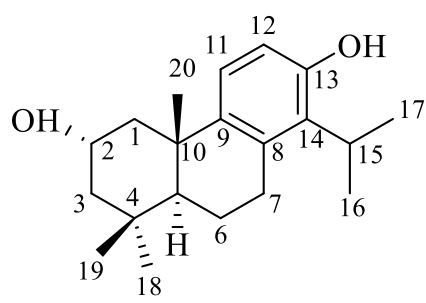

Figure 1. The chemical structure of millipedine A (10)

Compound 10, millipedine $\mathrm{A}$, was isolated as white powder, its molecular formula was determined to be $\mathrm{C}_{20} \mathrm{H}_{30} \mathrm{O}_{2}$ on the basis of HR-APCI-MS at $\mathrm{m} / \mathrm{z} 301.2163[\mathrm{M}-\mathrm{H}]^{-}$, (calcd for $\mathrm{C}_{20} \mathrm{H}_{29} \mathrm{O}_{2}^{-}, 301.2168$ ), indicating 6 degrees of unsaturation. The IR spectrum of 10 showed absorption bands for hydroxyl group $\left(3400 \mathrm{~cm}^{-1}\right)$ [15].

The ${ }^{1} \mathrm{H}$ NMR spectrum showed the presence of an $\mathrm{AB}$ system aromatic ring signals at $\delta_{\mathrm{H}} 6.98$ $(1 \mathrm{H}, \mathrm{d}, J=8.5 \mathrm{~Hz})$ and $6.50(1 \mathrm{H}, \mathrm{d}, J=8.5 \mathrm{~Hz})$, a isopropyl signals attached to the benzene ring at $\delta_{\mathrm{H}}$ $1.33(3 \mathrm{H}, \mathrm{d}, J=7.1 \mathrm{~Hz}), 1.32(3 \mathrm{H}, \mathrm{d}, J=7.1 \mathrm{~Hz})$, and $3.26(1 \mathrm{H}, \mathrm{m})$, three methyl signals at $\delta_{\mathrm{H}} 0.99$, 0.94, and 1.18 (each $3 \mathrm{H}, \mathrm{s})$, four methylene signals at $\delta_{\mathrm{H}} 1.28(1 \mathrm{H}, \mathrm{m}, \mathrm{H}-1), 2.55(1 \mathrm{H}, \mathrm{m}, \mathrm{H}-1), 1.28$ (1H, m, H-3), 1.83 (1H, ddd, $J=12.3,4.1,2.2 \mathrm{~Hz}, \mathrm{H}-3), 1.64$ (1H, m, H-6), 1.91 (1H, m, H-6), 2.75 $(1 \mathrm{H}, \mathrm{m}, \mathrm{H}-7)$, and $2.95(1 \mathrm{H}, \mathrm{m}, \mathrm{H}-7)$, as well as five methyne signals at $\delta_{\mathrm{H}} 4.01(1 \mathrm{H}, \mathrm{tt}, J=11.5,4.1$ $\mathrm{Hz}), 1.27(1 \mathrm{H}, \mathrm{m}), 6.50(1 \mathrm{H}, \mathrm{d}, J=8.5 \mathrm{~Hz}), 6.98(1 \mathrm{H}, \mathrm{d}, J=8.5 \mathrm{~Hz})$, and $3.26(1 \mathrm{H}, \mathrm{m})$. The ${ }^{13} \mathrm{C} \mathrm{NMR}$ and DEPT spectra showed 20 carbon signals, including five primary carbon signals at $\delta_{\mathrm{C}} 20.5,20.5$, 22.7, 26.3, and 33.5, four secondary carbon signals at $\delta_{\mathrm{C}} 19.2,28.7,48.9$, and 51.0, five tertiary carbon signals at $\delta_{\mathrm{C}} 27.5,49.1,66.1,114.6$, and 122.9 , six quaternary carbon signals at $\delta_{\mathrm{C}} 34.9,39.6,131.4$, 133.7, 142.3, and 152.4. These NMR data above showed that compound $\mathbf{1 0}$ has an abietane diterpene skeleton [16]. The HMBC correlations (Figure 2$)$ of $18-\mathrm{CH}_{3}\left(\delta_{\mathrm{H}} 0.99\right)$ to $\mathrm{C}-4\left(\delta_{\mathrm{C}} 34.9\right)$, to $\mathrm{C}-5\left(\delta_{\mathrm{C}}\right.$ $49.1)$ and $19-\mathrm{CH}_{3}\left(\delta_{\mathrm{H}} 0.94\right)$ to $\mathrm{C}-4\left(\delta_{\mathrm{C}} 34.9\right)$, to $\mathrm{C}-3\left(\delta_{\mathrm{C}} 51.0\right)$, indicated that $18-\mathrm{CH}_{3}$ and $19-\mathrm{CH}_{3}$ were located at C-4. The HMBC correlations of $20-\mathrm{CH}_{3}\left(\delta_{\mathrm{H}} 1.18\right)$ to $\mathrm{C}-10\left(\delta_{\mathrm{C}} 39.6\right)$, to C-1 $\left(\delta_{\mathrm{C}} 48.9\right)$, C-9 $\left(\delta_{\mathrm{C}} 142.3\right), \mathrm{C}-5\left(\delta_{\mathrm{C}} 49.1\right)$, indicated that $20-\mathrm{CH}_{3}$ was located at C-10. The HMBC correlations of $\mathrm{H}-16$ $\left(\delta_{\mathrm{H}} 1.33\right)$ to $\mathrm{C}-15\left(\delta_{\mathrm{C}} 27.5\right)$, to $\mathrm{C}-17\left(\delta_{\mathrm{C}} 20.5\right)$, to C-14 $\left(\delta_{\mathrm{C}} 152.4\right), \mathrm{H}-17\left(\delta_{\mathrm{H}} 1.32\right)$ to $\mathrm{C}-15\left(\delta_{\mathrm{C}} 27.5\right), \mathrm{C}-$ $16\left(\delta_{\mathrm{C}} 20.5\right), \mathrm{C}-14\left(\delta_{\mathrm{C}} 152.4\right)$, positioned the isopropyl group at C-14. The HMBC correlations of $\mathrm{H}-7$ $\left(\delta_{\mathrm{H}} 2.95,2.75\right)$ to $\mathrm{C}-8\left(\delta_{\mathrm{C}} 133.7\right)$, to $\mathrm{C}-9\left(\delta_{\mathrm{C}} 142.3\right)$, to C-14 $\left(\delta_{\mathrm{C}} 152.4\right)$, showed the aromatic hydroxyl located at C-14. The HMBC correlations of $\mathrm{H}-1\left(\delta_{\mathrm{H}} 2.55,1.28\right)$ to $\mathrm{C}-2\left(\delta_{\mathrm{C}} 66.1\right)$, and $19-\mathrm{CH}_{3}\left(\delta_{\mathrm{H}} 0.94\right)$ to $\mathrm{C}-3\left(\delta_{\mathrm{C}} 51.0\right)$, established the presence of a hydroxyl at C-2. The vicinal coupling constants of $\mathrm{H}-2$ (tt, $J=11.5,4.1 \mathrm{~Hz}$ ) showed $\mathrm{H}-2$ at axial orientation, means the hydroxyl at C-2 with $\alpha$ configuration [17]. The NOESY correlations of H-2 $\left(\delta_{\mathrm{H}} 4.01\right) / 19-\mathrm{CH}_{3}\left(\delta_{\mathrm{H}} 0.94\right), \mathrm{H}-2\left(\delta_{\mathrm{H}} 4.01\right) / 20-\mathrm{CH}_{3}\left(\delta_{\mathrm{H}} 1.18\right)$, and $19-\mathrm{CH}_{3}\left(\delta_{\mathrm{H}} 0.94\right) / 20-\mathrm{CH}_{3}\left(\delta_{\mathrm{H}} 1.18\right)$ further confirmed the relative stereochemical structures of compound 10. Accordingly, the structure of compound $\mathbf{1 0}$ was established and named millipedine A. 
A new terpenoid from Millipede

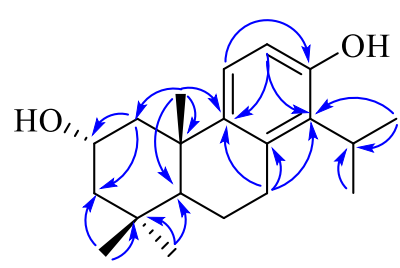

HMBC

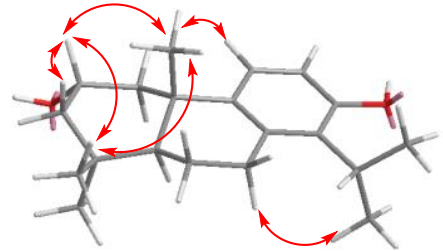

$\frown$ NOESY

Figure 2. Key HMBC and NOESY correlations of compound 10

The in vitro cytotoxicities of compound 10 against A549, HCT-116 and SW1990 cell lines were tested by the MTT assay [18-20]. Compound 10 exhibited moderate cytotoxicity against A549, HCT116 , and SW1990 cell lines in a dose-dependent manner, and the $\mathrm{IC}_{50}$ values were $61.81,46.83$, and $70.69 \mu \mathrm{M}$, respectively (Figure 3).

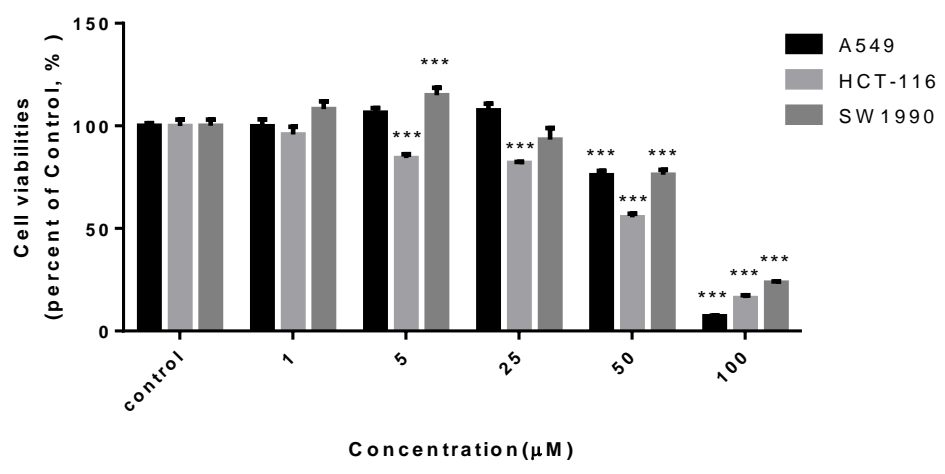

Figure 3. Cytotoxicity of compound $\mathbf{1 0}$

(Results are expressed as mean \pm SEM. Statistical significance compared to the control, $* * * \mathrm{p}<0.001$.)

\section{Acknowledgments}

This work was partially supported by the National Natural Sciences Foundation of China (No. 82060706), Science and Technology Department of Guizhou Province (QKHPTRC[2017]5733-017).

\section{Supporting Information}

Supporting Information accompanies this paper on http://www.acgpubs.org/journal/recordsof-natural-products

\section{ORCID}

Zhimei Shang: 0000-0002-8346-2678

Yike Fang: 0000-0002-2831-9684

Zongyu Yang: 0000-0001-9846-1531

Wanli Luo: 0000-0002-9560-9614

Xiaofei Li: $0000-0003-2409-9132$

Shiji Xiao: $\underline{0000-0002-2420-0790}$ 
Shang et al., Rec. Nat. Prod. (202X) X:X XX-XX

\section{References}

[1] J. D. Li, L. Q. Huang and X.B. Qu (2013). Medicinal fauna of China, Fujian Science Press, Fujian, China.

[2] Y. Q. Liu, M. T. Bian and C. K. Li (1984). Analysis of effective anticancer constitutes of Spirobolus bungii brandt by GC/MS, J. Chinese. Mass. Spectro. Soc. 5, 31-34.

[3] T. L. Jiang, S. C. Yan, S. F. Wang, G. W. Feng, L. F. Li and G. L. Wu (1981). Effect of extracts of Spirobolus bungii on transplanted tumors in mice, J. Tradit. Chin. Med. 1, 27-33.

[4] T. L. Jiang, G. W. Feng, J. H. Shen, L. F. Li and X. Q. Fu (1981). Observation of the effect of Spirobolus bungii extract on cancer cells, J. Tradit. Chin. Med. 1, 34-38.

[7] X. W. Yang and Y. P. Bai (1994). Studies on the chemical constituents of the pilose antler of red deer (Cervus elaphus), Chin. Tradit. Herb. Drugs. 25, 229-278.

[8] G. K. Wang, B. B. Lin, M. Tian, K. Zhu, G. Y. Xie and M. J. Qin (2017). Studies on chemical constituents from the roots of Bombax ceiba, J. Trop. Subtrop. Bot. 25, 387-393.

[9] L. Q. Wang, Q. L. Xu, L. M. Dong, Q. Zhang and J. W. Tan (2017). Chemical constituents from the fruit shell of Camellia oleifera, J. Trop. Subtrop. Bot. 25, 81-86.

[10] L. Jia, M. M. Guo, D. Li and L. L. Jing (2011). Chemical constituents from petroleum ether portion of Abelmoschus escu lentus II, China. J. Chin. Mater. Med. 36, 891-895.

[11] A. Halldorsson, P. Thordarson, B. Kristinsson, C. D. Magnusson and G. G. Haraldsson (2004). Lipasecatalysed kinetic resolution of 1-O-alkylglycerols by sequential transesterification, Tetrahedron. Asymmetry. 15, 2893-2899.

[12] W. J. Guo, G. L. Li, Y. X. Hou, R. R. Wang, Y. Liu, H. Gao and W. Wang (2017). Chemical constituents from the red alga Symphyocladia latiuscula, J. Chin. Pharm. Sci. 26, 754-762.

[13] Q. Yang and G. Ye (2009). A new c-glucoside from Commelina communis, Chem. Nat. Compd. 45, 5960.

[14] X. Yao, F. Tang and Y. D. Yue (2016). Chemical constituents from the culm of Dendrocalamus farinosus, Sci. Silvae. Sin. 52, 99-105.

[15] Z. M. Shang, X. F. Li and S. J. Xiao (2020). Two new bibenzyl compounds from Dendrobium lindleyi, Rec. Nat. Prod. 14, 416-420.

[16] C. I. Chang, C. C. Cheng, S. Y. Wang, J. J. Chen, M. J. Cheng, M. D. Wu, M. H. Tseng, C. R. Chen and Y. H. Kou (2020). Two new dimeric abietanoid peroxides with xanthine oxidase and ACE inhibitory activities from the bark of Cryptomeria japonica, Phytochem. Lett. 40, 15-20.

[17] S. J. Xiao, D. B. Shi, Z. L. Yuan, Y. Z. Chen, M. S. Zhang, L. S. Ding and Y. Zhou (2016). Two new rearranged lanostane triterpenoids from Tsuga longibracteata, Chin. J. Org. Chem. 36, 1686-1689.

[18] L. Cheng, D. L. Guo, M. S. Zhang, L. Linghu, S. B. Fu, Y. Deng, Y. Q. Hu and S. J. Xiao (2020). Dihydrophenanthrofurans and bisbibenzyl derivatives from the stems of Dendrobium nobile. Fitoterapia, 143, 104586.

[19] D. L. Guo, L. Qiu, D. Feng, X. He, X. H. Li, Z. X. Cao, Y. C. Gu, L. Mei, F. Deng and Y. Deng (2020). Three new a-pyrone derivatives induced by chemical epigenetic manipulation of Penicillium herquei, an endophytic fungus isolated from Cordyceps sinensis, Nat. Prod. Res. 34, 958-964.

[20] G. Y. Liu, L. Tan, L. Cheng, L. S. Ding, Y. Zhou, Y. Deng, Y. Q. He, D. L. Guo and S. J. Xiao (2020). Dendrobine-type alkaloids and bibenzyl derivatives from Dendrobium findlayanum, Fitoterapia, 142, 104497.

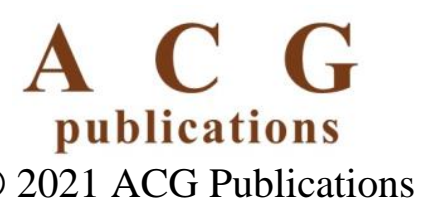

